DOI: $10.19195 / 2082-8322.15 .7$

LIGIA ŚLĘZAK

ORCID: 0000-0001-8644-4056

UNIWERSYTET WROCŁAWSKI

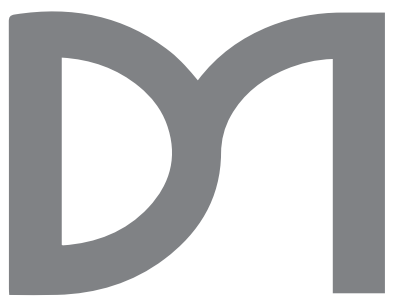

BADANIA NAD HUMOREM ŻEŃSKIM

W AKOMPANIAMENCIE MUZYKI NIE ZAWSZE POWAŻNEJ

I PRZY PROCENCIE ALKOHOLOWYM -

NA PODSTAWIE PROGRAMU „LASKOWIK \& MALICKI”

\title{
Research on female humor to the accompaniment of not-always-serious music and some alcohol - based on the Laskowik \& Malicki program
}

\section{Summary}

The article contains a description of the entertainment TV program Laskowik \& Malicki. It is an event combining cabaret and music, with performances from two artistic groups: Kabareciarnia Laskowika and The Philharmonic of Wit. The author stresses the topics of feminity, music and alcohol, as well as finds moralizing and educational value in the performances. television

Keywords: entertainment, cabaret, music, satire, humor, parody, joke, philharmonic, opera, song,

\section{Wprowadzenie}

Celem niniejszego artykułu jest opis zjawiska, jakim jest widowisko telewizyjne „Laskowik \& Malicki". Zostanie w nim położony nacisk na charakterystyczne cechy programu, czyli wykorzystaną muzykę oraz pojawiające się motywy kobiece, a także element poboczny, acz wpisujący się w tradycję polskiego humoru, czyli wątek alkoholowy, będące zresztą jednymi z najstarszych motywów występujących w światowym humorze. Program tworzyli 
w dużej mierze artyści o długoletnim doświadczeniu scenicznym, mający swoich wielbicieli o określonych oczekiwaniach, kontynuowali więc tradycję dawnych scen, w tym wspomniane kwestie. Wszystkie analizowane w tym tekście cytaty pochodzą z odcinków spektaklu.

To istotny temat, ponieważ mimo że powstaje coraz więcej publikacji dotyczących zjawiska kabaretu, żadna z nich nie opisuje wszystkich kwestii tak wyczerpująco, by nie dało się poruszyć kolejnych wątków związanych z tym tematem. Sam program rozrywkowy, jakim jest "Laskowik \& Malicki”, nie doczekał się żadnego opracowania. Pozycje, które podsumowują dorobek artystów tworzących Kabareciarnię Laskowika, są tekstami o ich dawniejszej twórczości, brakuje prac na temat ich dokonań najnowszych. Tekstów o komizmie muzycznym nie ma dużo, uwagę polskich badaczy zwróciła Grupa MoCarta, nie zaś zjawisko z pogranicza kabaretu, jakim jest Filharmonia Dowcipu.

"Laskowik \& Malicki" to telewizyjny program rozrywkowy produkowany w latach 2009-2010, zwykle emitowany w niedzielę, stąd podtytuł „Niedziela Wieczór”. Tworzyli go artyści reprezentujący odmienne rodzaje humoru: Kabareciarnia Laskowika, pianista Waldemar Malicki oraz zespół muzyczny Filharmonia Dowcipu, przy gościnnym udziale innych wykonawców. Widowisko ma cechy literacko-muzyczne, żart słowny przeplata się z dźwiękami instrumentów, ważnym elementem zjawiska są także efekty wizualne.

Warto przybliżyć obie grupy twórców. Zenon Laskowik to popularny komik, znany ze swej działalności kabaretowej w czasach PRL. Rozpoczął ją w studenckim kabarecie Klops, ale prawdziwą sławę przyniósł mu działający w latach sześćdziesiątych i siedemdziesiątych poznański kabaret Tey, w którym pracował razem z Krzysztofem Jaślarem, Aleksandrem Gołębiowskim, Bohdanem Smoleniem, Rudim Schubertem oraz Januszem Rewińskim. Teya charakteryzował przede wszystkim dowcip o nacechowaniu politycznym, ośmieszający ustrój, choć, jak stwierdził Bohdan Smoleń ${ }^{2}$, twórcy wcale nie sądzili, że naprawdę z kimkolwiek walczą, a ich sztuka coś zmieni. Kabareciarnia Laskowika jest tworem o zupełnie nowej jakości. W jej skeczach polityka oczywiście się pojawia, ale trudno powiedzieć, żeby to rzeczywiście były żarty skierowane przeciw komuś, atakujące jakąś opcję polityczną, nie mają także cech afirmatywnych (Michael Fleischer ${ }^{2}$ podaje, że kabaret właściwie w ogóle takich nie ma). Są to jedynie dowcipy z osób aktualnie znanych, humor jest delikatniejszy. Polityka nie jest jedynym źródłem dowcipu i występuje większa różnorodność tematyczna skeczów. Grupa została utworzona razem z innymi zasłużonymi kabareciarzamiª ${ }^{3}$ twórcą Zielonogórskiego Zagłębia Kabaretowego Władysławem Sikorą (znanym głównie z kabaretu Potem) oraz Jackiem Fedorowiczem, do którego dokonań zaliczyć można między innymi założenie gdańskiego Teatru Bim-Bom, a także prowadzenie satyrycznego programu „Dziennik Telewizyjny". Choć z samą Kabareciarnią współpracowało wielu artystów, na ekranach występowali: Zenon Laskowik, Jacek Fedorowicz, Grzegorz Tomczak, Andrzej Piątek, Krzysztof Kiełpiński, Julia Mikołajczak, Adriana Biernacka i, związana od 2014 roku z Formacją Chatelet, Barbara Tomkowiak.

Filharmonia Dowcipu to zespół muzyczny założony przez pianistę Waldemara Malickiego, dyrygenta i kompozytora Bernarda Chmielarza oraz reżysera Jacka Kęcika. Poza wymienionymi w skład formacji wchodzą wokaliści operowi - w czasie tworzenia programu

\footnotetext{
1 A.K. Kłys, B. Smoleń, Niestety, wszyscy się znamy, Kraków 2011, s. 87.

${ }^{2}$ M. Fleischer, Zarys teorii kabaretu, http://www.fleischer.pl/text/zarys_teorii_kabaretu.pdf (dostęp: 29.11.2021).

3 Używam słowa „kabareciarz”, choć część osób zapewne zapyta, czy nie jest to określenie deprecjonujące. Sądzę, że nie, ponieważ sami artyści reprezentujący różne kabarety często określają się właśnie tym mianem. Fleischer proponuje termin „kabaretysta”, jednak forma „kabareciarz” zdaje się występować znacznie częściej.
}

Dziennikarstwo i Media 15, 2021

(C) for this edition by CNS 
współtworzyli ją Anita Rywalska, Renata Drozd, Kamil Pękala, Marcin Pomykała i Krystian Krzeszowiak, a także orkiestra, której skład byłby zbliżony do orkiestry symfonicznej, gdyby nie stosowanie instrumentów elektronicznych, takich jak keyboard, gitara elektryczna, skrzypce elektryczne.

\section{Czy to kabaret?}

O ile Filharmonię Dowcipu nazwałam już „zjawiskiem z pogranicza kabaretu” - wszakże pojawiają się tu, tak jak we współczesnym kabarecie, dowcipy, jej koncerty składają się z następujących po sobie skeczów, jednakże trudno ją zakwalifıkować jako kabaret. Dlaczego? Oczywiście nie jest łatwo kabaret zdefiniować - ten dział sztuki ciągle się zmienia, a i u swego początku był czymś bardzo polimorficznym - przecież Chat Noir, Moulin Rouge, Le Mirliton oraz inne dawne kabarety łączyły w sobie wiele dziedzin artystycznych: taniec (w tym kankan), muzykę, scenki aktorskie, poezję, nawet teatr cieni. Jak pisałam już w artykule dotyczącym grup kabaretowych działających w Polsce Ludowej ${ }^{4}$, określić kabaret zjawiskiem muzyczno-literackim jest zbytnim uogólnieniem - w taką definicję wpisują się również musical czy opera. Zależnie od miejsca i czasu sztuka kabaretowa przybierała różne formy, często bardzo od siebie odmienne. Zupełnie różniły się od siebie Chat Noir, Elf Scharfrichter, Zielony Balonik, Kabaret Starszych Panów czy Tey, jeszcze inne są współczesne grupy, jak Kabaret Moralnego Niepokoju albo Kabaret Skeczów Męczących. W krajach zachodnich wyraz cabaret jest powiązany znaczeniowo z rewią. W czasach współczesnych w Polsce tym, co się kojarzy ze słowem „kabaret”, jest humor (choć historycznie kabaret nie zawsze zawierał w sobie elementy śmieszne - zarówno zagraniczny, jak i polski) i tego właśnie oczekuje widz, który włącza telewizor bądź idzie na występ danej grupy. Chce się po prostu śmiać.

Niemiecki badacz Jürgen Henningsen ${ }^{5}$ w swej pracy Theorie des Kabaretts stwierdza, że kabaret to przedstawienie złożone z krótkich scen zwanych skeczami i choć uważa, że jego nieodłączną częścią jest aktywna publiczność, współcześnie sztuka kabaretowa jest zjawiskiem medialnym - jest obecna w radiu, telewizji oraz internecie (multimedialność, elementy filmowe, $w$ tym transmisje, Fleischer ${ }^{6}$ określa jako typowe dla kabaretu). Odbiorca więc jest, nie zawsze jednak w tym samym miejscu i czasie, w którym występują wykonawcy, choć nie można stwierdzić, że jest z tego powodu nieaktywny. Wręcz przeciwnie. Aby żart został zrozumiany, wzbudził reakcję śmiechu, zarówno nadawca, jak i odbiorca muszą dysponować tym samym kodem kulturowym. Inną cechą kabaretu jest zasada konstrukcyjna - spektakl składa się z krótkich scenek zwanych skeczami. Kolejne, na co wskazuje badacz, to zasada ograniczonych środków. Skecze są krótkie, trzeba jasno zasygnalizować znaczenie przekazu. Scena często nie jest duża, co też powoduje zagęszczenie środków oraz brak tworzenia iluzji. W przeciwieństwie do kabaretu Filharmonia Dowcipu ma szansę operować większą liczbą środków, na dodatek stosując rekwizyty, których użycie w kabarecie jest opcjonalne, mogą nawet nie występować.

Rola kabareciarza w koncepcji Henningsena jest potrójna. Po pierwsze, jest to rola narzucana przez skecz, po drugie - rola komika, po trzecie - artysta reprezentuje sam siebie.

\footnotetext{
4 L. Ślęzak, Kabaret Pod Egidą, Tey, Elita i „Studio 202” wobec rzeczywistości PRL-u, „Szkice Humanistycze" 2018, nr 1-2, s. 45.

5 Za: M. Fleischer, op. cit., s. 2.

6 Ibidem.
}

Dziennikarstwo i Media 15, 2021

(C) for this edition by CNS 
Ta trzecia rola jest o tyle istotna, że jeśli artysta jest darzony sympatią widza, ten chętnie będzie śledził jego twórczość. Nie jest bez znaczenia to, co Marek Perepeczko powiedział Michałowi Pałubskiemu7, dawnemu członkowi Formacji Chatelet i dzisiejszemu monologiście: bycie aktorem kabaretowym jest trudniejsze niż aktorstwo teatralne lub filmowe, bo kabareciarza publiczność musi lubić, żeby się dobrze bawić. Rzeczywiście - aby obejrzeć film lub sztukę teatralną z przyjemnością, widz nie musi darzyć aktora sympatią, natomiast idąc na występ kabaretowy, sugeruje się tym, czy występują artyści, których lubi. Warto zauważyć, że w "Laskowiku \& Malickim” artyści grają siebie, używają prawdziwych imion oraz nazwisk, mimo że ich charakter na scenie jest tylko kreacją, mimicry, niekoniecznie mającą wiele wspólnego z ich prawdziwą tożsamością. Kryteria Henningsena są spełniane przez Kabareciarnię, przez Filharmonię Dowcipu natomiast częściowo. Tę ostatnią uznałabym więc za zjawisko łączące w sobie cechy kabaretu i zespołu muzycznego.

Sama nazwa "kabaret” jest wywodzona od francuskich słów cave - „piwnica”, „szynk” oraz et, czyli „i”. Wskazuje to na miejsce, w jakim kabaret powstał, a właściwie na to, czym był z początku, czyli jednocześnie formą sztuki i miejscem - jak w wypadku pierwszego z nich: Chat Noir. Dziś kabaret jest kojarzony z grupą wykonawców. Może wystąpić zarówno w lokalu wielkości kawiarni, klubu, baru, jak i w amfiteatrze. Stracił więc swoją kameralną atmosferę, ale występ w warunkach pierwotnych nie jest dla niego problemem. Jednak jeśli porównać składy grup kabaretowych, zazwyczaj nie tworzy ich wielu artystów, często są to dwie, trzy, cztery albo pięć osób. Kabareciarnię można jeszcze zakwalifikować jako kabaret między innymi dlatego, że poradzi sobie nawet na małej scenie. W Filharmonii Dowcipu bardzo ważny jest charakter wizualny, skład zespołu jest liczny, a samo rozstawienie instrumentów muzycznych i potrzebnych urządzeń powoduje, że scena musi być większych wymiarów. Skutkuje to tym, że można ją raczej określić jako zespół muzyczny niż kabaret muzyczny, taki jak na przykład kwartet tworzący Grupę MoCarta, którego instrumenty smyczkowe są łatwiejsze do przewiezienia i użycia w małym pomieszczeniu niż cały zestaw różnych instrumentów. Mamy zatem przykład synkretycznego wytworu, łączącego w sobie elementy kabaretu, filharmonii i opery.

Tematykę i zagadnienia związane ze scenami Filharmonii Dowcipu i Kabareciarni można rozpatrywać w różny sposób. Znaczący jednak jest wątek kobiecy, zwykle osadzony w humorze dotyczącym spraw damsko-męskich, oraz muzyka, która zajmuje znaczną część programu. W tekście zostanie również poruszony problem występujący bardziej marginalnie, czyli alkohol.

\section{Komizm}

Komizm bywa różny. Istnieje komizm sytuacyjny, komizm postaci i komizm słowny. Sceny zawarte w „Laskowiku \& Malickim” zawierają wszystkie te rodzaje. Jednak komizm nie jest definiowany zawsze tak samo. Naukowcy sprzeczają się nawet, czy humor, śmieszność i komizm są tym samym. Z pewnością satyra, wiążąca się z krytyką, nie zawsze jest śmieszna, komizm także nie zawsze śmiech wywołuje. Władysław Sikora ${ }^{8}$ określa dobre i śmieszne skecze „komicznymi”, a jedynie zabawne „śmiesznymi”. Śmieszność w jego zamyśle powo20.02.2021).

7 M. Chudziński, Reżyserować siebie, https://bosko.pl/kultura/Rezyserowac-siebie.html (dostęp:

8 W. Sikora, Śmieszne a dobre, http://sikora.art.pl (dostęp: 20.02.2021).

Dziennikarstwo i Media 15, 2021

(C) for this edition by CNS 
dują różne elementy, komizm zaś wynika z dobrego przemyślenia sceny i zawiera postaci, jak określa, „wyraziste”, czyli niebędące śmiesznymi same w sobie. Dowcipny charakter scenki wynika z tego, jak się rozwijają akcja i dialogi.

Kabaret i pokrewne mu zjawiska posługują się parodią, ironią, satyrą. Ted Cohen ${ }^{9}$ pisze o dowcipie czystym i warunkowym. Pierwszy rodzaj miałby oddziaływać na każdego widza, drugi zaś tylko na niektórych. Producenci programów dostarczających rozrywkę, czy to telewizyjnych, czy spektakli na żywo, stawiają sobie za cel dotarcie do jak najszerszej publiczności. Jednakże, po pierwsze, poczucie humoru to sprawa indywidualna i jeden dowcip może wywołać wiele różnych reakcji; po drugie, by zrozumieć zabiegi tekstowe, trzeba być zakotwiczonym w tym samym kodzie kulturowym co nadawca, wiedzieć o najnowszych wydarzeniach, na przykład medialnych, politycznych, do których twórca może się odnosić. W tym kontekście muzyka, będąca czymś, co jest niewerbalne, zdaje się docierać do szerszej publiczności, nie tylko z danego kręgu kulturowego, ale już humor oparty na teorii muzyki, który również jest w widowiskach Filharmonii Dowcipu, może być dobrze zrozumiany przez nielicznych, czyli tych, którzy posiedli pewną wiedzę na temat muzyki.

Dla badacza Clifforda Geertza ${ }^{10}$ kultura jest podobna do języka, dlatego że to ona pozwala człowiekowi zrozumieć innych. W interpretacji ważny jest kontekst, a jeden znak gest, ruch, słowo - może mieć wiele znaczeń i są one zależne od sytuacji, w której występują. Ta niejednoznaczność jest istotna dla twórcy kabaretowego, bawiącego się siatkami znaczeniowymi, jak również dla odbiorcy, który rozkodowuje coraz to nowe znaczenia. Istotne jest więc połączenie semiologii oraz hermeneutyki - ważna jest relacja znaku ze znaczonym, ale także przedsądy, czyli wiedza, jaką ma odbiorca widowiska. Pozwala mu ona zarówno docenić humor, jak i zdystansować się do niego.

Zjawiska ludyczne nabierają coraz większego znaczenia, bo są coraz bardziej pożądane przez odbiorcę, który relaksuje się przez śmiech i rozrywkę. R. Nycz ${ }^{11}$, pisząc o parodii, stwierdził, że jej rola rośnie, a jest ona jednym z popularnych zabiegów humorystycznych, także w opisywanych spektaklach. „Laskowik \& Malicki” to także przykład karnawalizacji kultury. Chodzi o karnawał w bachtinowskim rozumieniu, pełen groteski, satyry, parodii i komizmu, w którym powaga może się mieszać ze radością. Tak też jest w tym programie - muzyka klasyczna, elementy refleksyjne przeplatają się z tym, co popularne, jarmarczne i śmieszne.

\section{Kobiety}

\section{Wykonawczynie}

Zagadnienie kwestii kobiecej w kabarecie jest niezmiernie interesujące. Na polskiej scenie kabaretowej kobiet jest zdecydowanie mniej niż mężczyzn, na dodatek często zdają się pełnić funkcję ozdoby lub tła. Częsty brak przedstawicielek płci pięknej w składzie zapoczątkował tradycję istniejącą do dziś (a mającą starożytne korzenie w greckiej tragedii czy teatrze kabuki), wedle której kobietę może śmiało zagrać mężczyzna. Zdarzyło się to także

9 T. Cohen, Dowcipy. Filozoficzne rozważania o dowcipnych sprawach, [w:] B. Dziemidok, o komizmie, Gdańsk 2011, s. 483-484.

10 C. Geertz, Interpretacja kultur, wybrane eseje, przeł. M.M. Piechaczek, Warszawa 2006, s. 18-47.

11 R. Nycz, Parodia i pastisz. Z dziejów pojęć artystycznych w świadomości literackiej XX wieku, [w:] idem, Tekstowy świat. Poststrukturalizm a wiedza o literaturze, Warszawa 1993, s. 233-235.

Dziennikarstwo i Media 15, 2021

(C) for this edition by CNS 
na scenie Laskowika, gdy Kiełpiński zagrał zatroskaną o syna matkę i żonę męża zajętego czytaniem gazety. Jeśli rolę żeńską odgrywa mężczyzna, nie przedstawia on zwykle kobiety atrakcyjnej, tak też dzieje się i tu - co dobitnie obrazuje dialog matki z synem, wypytującej się o imprezę, na którą ten się wybiera:

Syn: Będą fajne laski.

Matka: Fajne laski? 0 mnie też tak za plecami mówisz?

[...]

Ojciec: Matka!... Matka! Jakbyś ty była laską... To ja bym się czuł marszałkiem sejmu!12

Matka uważa określenie „fajna laska” za brak szacunku, ojciec i syn za określenie ładnej dziewczyny, wykorzystana też zostaje wieloznaczność tego słowa, określającego osobę i przedmiot, żeby podkreślić, że wskazana postać w żadnym wypadku „laską" nie jest.

Niewiastę gra sam Zenon Laskowik, a konkretnie podstarzałą autostopowiczkę pragnącą odwiedzić brata we Wronkach, niebroniącą się przed zainteresowanym nią kierowcą, nawet dającą na to zezwolenie. Finalnie nie dochodzi do niczego, jednak staruszka z rozrzewnieniem wspomina napotkanego mężczyznę.

Charakterystyczne dla kreacji kobiecej reprezentowanej przez mężczyznę w kabarecie jest to, że odbiorca może się zorientować, jakiej płci jest aktor. Kabareciarz nie upodabnia się do kobiety zupełnie. Zakłada strój i perukę, ale nie goli się, nie ma na sobie dużo makijażu (jeżeli w ogóle), a przecież umiejętności charakteryzatorów filmowych i teatralnych pozwalają na oszukanie oczu oglądających. Z jednej strony kabaret jest antyiluzoryczny, chodzi o umowność, oszczędność środków, z drugiej - wpływa na to pożądany efekt śmieszności.

W dzisiejszych czasach, jeśli w grupie kabaretowej w ogóle występuje kobieta, to bardzo często jest tam jedyną reprezentantką płci żeńskiej. Wśród medialnych kabaretów wyjątki są nieliczne - jak istniejące niegdyś Babeczki z Rodzynkiem, w którym był tylko jeden mężczyzna, nieistniejący już kabaret Szum, składający się z trzech aktorek, później przekształcony w Słoiczek po Cukrze (grały dwie z nich) oraz towarzyszący kabaretowi Koń Polski chórek Koniczynki, składający się z trzech piosenkarek. W Kabareciarni Laskowika na wizji występowały trzy artystki.

W całym programie kobiet znalazło się znacznie więcej. Żeńska jest prawie cała sekcja smyczkowa Filharmonii Dowcipu (wyjątkiem jest koncertmistrz, co Malicki w programie tłumaczy stwierdzeniem, że lubi kobiety). W grupie występowały dwie sopranistki.

Oczywiście skład zespołu muzycznego i kabaretu nie zawęża się do przedstawicielek płci pięknej występujących w programie, gdyż gościnnie wystąpiły także tancerki, zespół folklorystyczny, teatrzyk Klimaterium, tworzony przez znane aktorki - Krystynę Sienkiewicz, Elżbietę Jodłowską, Igę Cembrzyńską, Mirosławę Krajewską.

\section{Wygląd kobiet}

Warto przyjrzeć się wyglądowi kobiet w programie. Kobiecy sekstet smyczkowy nie jest ubrany w sposób typowy dla artystek filharmonii czy opery. Nie są to stroje oficjalne, jakich wymaga etykieta w takich instytucjach. Jak więc wyglądają? Stroje są błyszczące i wielobarwne: krótkie spódniczki, szorty, legginsy i inne obcisłe ubrania, mają dekolty - czyli wszystko, co podkreśla atrakcyjność kształtów grających. Na temat ich wyglądu najlepiej wypowiada się w żartobliwym tonie w jednym ze skeczów sam pianista, tłumacząc, jak skrzypaczki i wiolonczelistki otrzymują pracę. Mianowicie CV do Filharmonii Narodowej powinno

12 „Laskowik \& Malicki. Niedziela Wieczór”, TVP 2009-2010.

Dziennikarstwo i Media 15, 2021

(C) for this edition by CNS 
wyglądać tak: „Ukończyłam akademię muzyczną, jestem laureatką Konkursu Skrzypcowego im. Wieniawskiego, moja specjalność to arpeggio w koncercie Mendelssohna", do Opery Narodowej: „Ukończyłam akademię muzyczną, jestem laureatką Międzynarodowego Konkursu Wiolonczelowego w Mediolanie, moja specjalność to spiccato w ostatnich symfoniach Brücknera”. CV do Filharmonii Dowcipu prezentuje się następująco: „Panie dyrektorze, ukończyłam akademię muzyczną, jestem laureatką Konkursu Skrzypcowego im. Wieniawskiego. Moje wymiary to $90 / 60 / 90 " 13$. Po wygłoszeniu tej informacji skrzypaczki, altowiolistki i wioIonczelistka wstają, prezentując swoje figury. Podania do Filharmonii Dowcipu mają napływać ciągle, co ma pozwalać muzykom „utrzymać koleżanki w dobrej formie”, ale ze względu na wygląd grających otrzymanie tam pracy w tym momencie ma być niemożliwe, co komentuje zagrany przez nie motyw z Mission Impossible.

Solistki występujące w spektaklu często ubrane są w piękne balowe lub wieczorowe suknie, ale miewają też krótkie spódniczki lub krótkie spodenki oraz topy. W jednym ze skeczów obie panie zrywają z siebie bluzki, szale, spódnice i zostają w body, co Malicki z Chmielarzem komentują stwierdzeniem, że nieźle się trzymają jak na swój wiek i „jest przyjemnie". Pianista innym razem komentuje aparycję Renaty Drozd, odnosząc się do istniejącego w kulturze stereotypu otyłej śpiewaczki, wywodzącego się z oper Wagnerowskich - twierdząc, że kiedyś sopranistka wyglądała jak hipopotam, a „panią Renatę od hipopotama różni wszystko. A od piranii tylko szminka", co może być sygnałem złośliwego charakteru opisywanej. Warto podkreślić, że obie solistki są wysokie i mają blond włosy. Bernard Chmielarz objaśniał, że specjalnie szukano do zespołu śpiewaczki o podobnym wyglądzie do Drozd ${ }^{14}$.

Dowcip seksualny występuje w serii bardzo często i zdaje się jednym z głównych motywów. Występujące gościnnie tancerki także go reprezentują. Aneta Bałon występuje w roli muzy, która inspiruje artystów. Mężczyźni kolejno grają motyw znany także jako Mały elf z filmu Emanuelle na różnych instrumentach dętych, odrzucają ich części po zagraniu kolejnej partii melodii, ona zaś zrzuca kolejne części ubioru. Zostaje w samej bieliźnie. Jako ostatni gra pianista, muza podchodzi do fortepianu, podnosi podpórkę od jego skrzydła. Finalnie zostaje poinformowana, że nie ma już narzędzi do kontynuowania akcji, co komentuje słowem „trudno” i wychodzi. Wspomniana tancerka tańczy w podobnym stroju na rurze, charakteru komicznego nadaje tu wykonywanie tego w rytm romansu z Eine Kleine Nachtmüsick Mozarta, a wcześniej jeszcze gra na rzadko używanym instrumencie, czyli dzwonach rurowych. Pokaz tańca daje w celu udowodnienia, że nie ma jednak problemu z zarobkiem rurę wyciąga z jednego z dzwonów. Innym fragmentem programu, w którym można oglądać kobiecą bieliznę, jest skecz prezentujący muzykę rosyjską. W scenie uczestniczą, kolejno, śpiewaczki, aktorki kabaretowe oraz baletnice. Wykonywane są utwory Poluszko pole oraz Tańce połowieckie z opery Kniaź Igor. Kobiety stoją rzędem, kolejno odchodząc na bok i wykonując kroki imitujące ludowe tańce rosyjskie. Każda następna nie ma na sobie kolejnego elementu ubrania. Serdaka, fartuszka, spódnicy... Finalnie ostatnia zostaje w majtkach, staniku i czepcu. Puentą skeczu jest wejście Laskowika i Malickiego, którzy mówią, „że chciałoby się kontynuować ten pierwszy w historii rozbiór Rosji, ale to w paśmie nocnym po 22:00". Gra słów oparta na pokrewieństwie wyrazów „rozbiór” $i$ „rozbierać” nie jest tu przypadkowa.

Aktorki kabaretowe nie zadziwiają swym strojem, ponieważ w ich zawodzie nie istnieje ściśle wyznaczony dress code. Noszą zwyczajne barwne sukienki, bluzki, spódnice, eleganckie, lecz niekoniecznie wieczorowe. Jednakże jedna z nich, Barbara Tomkowiak, częściej pojawia się w bieliźnie, na przykład jako asystentka z telewizji prywatnej lub reklamując „pończoszki bezoczkowe”.

13 Ibidem.

14 Wyjaśnił mi to w prywatnej rozmowie.

Dziennikarstwo i Media 15, 2021

(C) for this edition by CNS 
Striptiz towarzyszący widowisku kabaretowemu nie jest nowością. Zjawisko znane było w kabarecie francuskim. Mało kto wie, że Teyowi także towarzyszył występ striptizerki (nadano jej „wypukłe imię" - „Cycylia”) i jej rola polegała na szukaniu przez cały spektakl ubrań na scenie. We współczesnym polskim kabarecie nikt nie epatuje zupełną nagością.

Humor z seksualnym podtekstem jest częsty u polskich grup kabaretowych, a także w innych formach rozrywkowych mających na celu rozśmieszenie widza. „Laskowik \& Malicki” nie odróżnia się więc pod tym względem od innych programów rozrywkowych, nie jest też wulgarny.

Oprócz młodych kobiet w scenach występują również osoby bardziej posunięte w latach. W skeczach z cyklu „Klimakterium” tytuł wskazuje na to, w jakim wieku mogą być wykonujące spektakl i czego on dotyczy, bohaterki przypominają więc typowe kobiety po menopauzie. Gościnnie pojawił się także zespół ludowy tworzony przez panie mające więcej niż pięćdziesiąt lat, ubrane w stroje regionalne. Wesołego zabarwienia nadaje scenie to, że baryton i tenor śpiewają piosenkę Wyginam śmiało ciało z filmu animowanego Madagaskar i przeinaczają słowa „Lubię, kiedy sensowne panienki wyginają wesołe ciałka” na „Lubię, kiedy seksowne panienki wyginają wesołe ciałka” ${ }^{15}$, patrząc na tańczące wokół radosne seniorki.

\section{Postaci wykreowane}

Postaci kobiece w Kabareciarni są zazwyczaj drugoplanowe. Występują jako kasjerki, klientki sklepu, pielęgniarki (jedną lekarz trzyma za siedzenie, co przedstawia częsty stereotyp występujący $\mathrm{w}$ dowcipach, a zatem i w kabarecie, o pielęgniarkach romansujących z lekarzami), kobiety z agencji matrymonialnej poszukujące męża - w tym: polonistka szukająca pana, który będzie „Ogniem i Mieczem”; roześmiana Laura, co szuka Filona, co klaszcze za borem i „liczy na niezły haj” (nawiązanie do Laury i Filona Franciszka Karpińskiego); kokietka; fascynatka kultury wschodniej; wdowa, która pochowała kilku mężów i pokocha następnego; niemówiąca wyraźnie po polsku obywatelka Puerto Rico. Występujące nie są ubrane specjalnie do ról, mają na sobie zwyczajne sukienki.

W programie świątecznym Barbara Tomkowiak personifikuje Młodość. Jest to nawiązanie do Ody do młodości. Na słowa poety „Młodości, dodaj mi skrzydła!” przynosi mu skrzydła i każe lecieć. Gdy dowiaduje się, że to tylko chwyt retoryczny, obdarowywany nie chce przyjąć prezentu, komentuje ją trawestacją Romantyczności - „Słuchaj dzieweczko - ona nie słucha. Pewnie cholera głucha!" ${ }^{16}$, nie mogąc namówić rozmówcy do wzięcia daru, wpada w gniew, i na zmianę ze św. Mikołajem bije go prezentem. Komizm tkwi w wypowiadanych kwestiach.

Charakterystyczne role są wykreowane w piosenkach, jakie trio wykonuje. Biernacka, śpiewając, wciela się w rolę studentki psychologii zafascynowanej Freudem, przekonanej, że mężczyźni jej pożądają. Mikołajczak w programie wielkanocnym wychodzi na scenę jako kiczowato wystrojona dziewczyna, która chce zostać znaną artystką, nie wiadomo, jak dostała się na scenę. Fałszując, śpiewa, jak będzie wyglądało jej życie jako gwiazdy, obrazując przy tym celebrycki sposób życia:

Taka gwiazda, taka znana,

W dzień i w nocy nie jest sama.

Doktorowie od plastiku d o d a dzą urodzie szyku.

Taka gwiazda to ma wszystko $\mathrm{w} d$...

15 „Laskowik \& Malicki. Niedziela Wieczór”, TVP 2009-2010.

16 Ibidem.

Dziennikarstwo i Media 15, 2021

(C) for this edition by CNS 
Sami wiecie.

Toalecie.

Tam fluid ma... i maszkarę...

Taka gwiazda dla kariery ma do roku śluby cztery

Potem zaraz ma rozwody

I tym zwiększa swe dochody.

Będę wypinać pośladki,

Paradować bez stanika!

Gwiazda to jest okaz rzadki.

I to kocha publika! ${ }^{17}$

Po czym prezentuje długie majtki ukryte pod spódniczką.

Ciekawą rolę grają solistki. Jak już wspomniałam, sopranistka jest określona jako atrakcyjna. Śpiewaczki przedstawione w scenach są kapryśne, spóźnialskie, złośliwie się do siebie odnoszą, na przykład: „- Wybaczcie, czekałam na fryzjera. - I co? Nie przyszedł?”, „- Ubezpieczyłam swój głos na milion złotych. - I coś ty zrobiła z tymi pieniędzmi?”, "- Chcę wyjść na scenę w czymś takim, co zaskoczy wszystkich”, „- Załóż łyżwy" ${ }^{8}$. Rywalizują, która wyda z siebie dłużej trwający dźwięk, przy Barkaroli zrywają z siebie ubrania. Pianista określa współpracę z nimi jako coś okropnego.

Wykonawczynie grają także w skeczach kogoś innego niż siebie. Na przykład w przedstawieniu dotyczącym różnych oblicz miłości grają przedstawicielki różnych narodowości i przedstawiają stereotypy - między innymi Rosjankę wykonującą kroki typowe dla rosyjskich tańców ludowych, narzekającą, że jej wybranek pije za dużo wódki, troskliwą Włoszkę, która nie może odciągnąć męża od oglądania meczu, podczas gdy na stole stygnie makaron, Niemkę o specyficznych, zdyscyplinowanych ruchach, rozpaczającą, że partner krzyczy przez sen Hände hoch!, czy Francuzkę zniesmaczoną zapachem sera z ust ukochanego.

Wykreowane postaci to nie tylko odegrane role, to także postaci w tekście. Zenon Laskowik ukazuje w swoich piosenkach pewne wzorce osobowe: zbuntowanej wnuczki Madzi, która nie chce się uczyć, robi błędy ortograficzne, „nie chce śpiewać w szkolnym chórze, ale chce tańczyć na rurze”, a którą dziadek próbuje przywołać do porządku, Czerwonego Kapturka - chudego, szpetnego, z pomarszczoną twarzą, który „ma ochotę na faceta”. Pojawia się także kobieta nieczuła - zaprezentowana w piosenkach Krzysztofa Kiełpińskiego - dziewczyna, która zostawia chłopaka w kawiarni i ucieka, niewierna Irenka, zdradzająca swojego ukochanego z innym, chomicza samica, nieodwzajemniająca uczuć zakochanego w niej chomika. W końcu występuje także motyw Świtezianki, lecz nie jako rusałki, która karze niewiernego mężczyznę, ale dziewczyny zapewnianej o miłości ukochanego.

Stereotypowe treści i traktowanie kobiet jako obiektu pożądania można by odebrać jako dyskryminujące, jednak widz zawiesza swą wiedzę o świecie, kiedy ogląda świat przedstawiony, co odsyła do Ingardenowskiej teorii quasi-sądów ${ }^{19}$. Mimo to każdy dowcip może obrażać, czy tak się dzieje - zależy od wrażliwości odbiorcy - ten wchodzi w zabawę z artystą, wie, że podobne sceny nie powinny się rozegrać w rzeczywistości. Gdyby natomiast się wydarzyły, byłyby jawnym przejawem seksizmu.

17 Ibidem.

18 Ibidem.

19 R. Ingarden, 0 tzw. „prawdzie” w literaturze, [w:] idem, Studia z estetyki, t. 1, Warszawa 1957, s. $329-439$.

Dziennikarstwo i Media 15, 2021

(C) for this edition by CNS 


\section{Muzyka}

\section{Muzyka klasyczna i popularna}

Muzyka jest głównym elementem programu. Jest wykonywana przez muzyków i kabareciarzy. Humor muzyczny dotyczy utworów, ale i tekstów. Obie grupy w podejściu do muzyki różni to, że Filharmonia Dowcipu wykonuje niemal wyłącznie znane utwory, a więc wtórne, prezentuje jedynie różne możliwości ich wykonania i zabawy z dźwiękiem, prawie nigdy nie przedstawia kompozycji autorskich. Kabareciarnia zaś prezentuje zupełnie nowe utwory. Jak podkreślił Fleischer ${ }^{20}$, twórca tekstu może być wykonawcą lub nim nie być, może też używać tekstów stworzonych specjalnie na potrzeby widowiska lub pochodzących z innego źródła. Tak właśnie rzecz ma się zarówno z warstwą tekstową, jak i z melodią. Sferę muzyczną programu można więc porównać do tego, co badacz określił jako teksty autorskie, czyli pisane specjalnie dla Kabareciarni, oraz teksty wtórne - te, które są przez Filharmonię Dowcipu użyte.

Orkiestra często wykonuje akompaniament dla kabaretu, ale w innych fragmentach programu to ona wysuwa się na pierwszy plan. Utwory grane przez zespół Malickiego nie są wykonywane tak, jak zostały przedstawione przez twórców. Okazuje się, że muzyka klasyczna może mieć charakter rozrywkowy, a popularna być wykonana w ten sposób jak poważna. Przykładowo, dzięki zastosowaniu synkopy, czyli przesunięcia rytmu, aria La ci da rem la mano Mozarta brzmi jak współczesny utwór rozrywkowy. W rockowym stylu zostaje wykonana Etiuda rewolucyjna - utwór fortepianowy wykonują orkiestra oraz śpiewacy, towarzyszy im dźwięk gitary elektrycznej, głośno brzmi perkusja. Habanera z Carmen zostaje przedstawiona w sposób przywodzący na myśl metal (na co wskazują też ruchy przypominające tak zwane moszowanie, czyli machanie włosami) lub rock. Piosenki z repertuaru piosenkarzy nurtu disco polo - Szalona, Żono moja - są zaśpiewane operowymi głosami, tak samo utwory muzyki pop, jak Macarena, Asereje, Znak pokoju Dody czy tematy filmowe. Oczywiście walorów humorystycznych dodają utworowi komentarze, jak zapowiedź utworu Dragostea din Tei mołdawskiego zespołu 0-Zone jako „baroku rumuńskiego”, którego największe osiągnięcia przypadają na wiek XXI.

Częste jest połączenie różnych utworów przez skojarzenia dźwiękowe bądź tematyczne. Dzieje się to wiele razy. Delikatna kompozycja Beethovena przechodzi w renesansowy angielski utwór Greensleeves (mylnie kojarzony z Irlandią), by w końcu zabrzmiał temat z musicalu Lord of the Dance. Carmina Burana Carla Orffa przemienia się w Bohemian Rapsody Queen, a po chwili przez słowo "mama” powoduje przeskok do Mamma Mia Abby. The Final Countdown grupy Europe przez energiczny akompaniament orkiestry dętej w pewnym momencie przechodzi w Upiora w operze, poemat symfoniczny Sibeliusa Finlandia za chwilę zmienia się w fińską kompozycję levan Polkka, znaną głównie za sprawą internetowego mema.

Przy tak wesołych aranżacjach widowisko nie traci walorów edukacyjnych. Malicki w żartobliwy sposób prezentuje, czym jest synkopa, kwinta, kwarta, pokazuje to na przykładzie orkiestry: kwintę reprezentują skrzypaczki i altowiolistki, a kwartę sekcja dęta. Pada teza, że kwinta z jakiegoś powodu jest atrakcyjniejsza dla kompozytorów. Zaczyna się wykonywanie na zmianę kwint i kwart, będące wstępem do utworu Chichuaua.

Filharmonia Dowcipu zapoznaje odbiorców z muzyką klasyczną, którą ci często znają głównie jako ścieżkę dźwiękową w filmach czy reklamach, nie znają jednak tytułu ani nie wiedzą, kto jest autorem.

20 M. Fleischer, op. cit., s. 4.

Dziennikarstwo i Media 15, 2021

(C) for this edition by CNS 
Nie brakuje dowcipów na temat kompozytorów. Pada stwierdzenie, że Edvard Grieg (zwany Chopinem Północy ze względu na skandynawskie pochodzenie) komponował mało, bo robił to tylko latem, a zima w Norwegii trwa jedenaście miesięcy i dwa tygodnie. Tytuł utworu Beethovena Do Elizy Malicki tłumaczy głuchotą kompozytora (z powodu której faktycznie cierpiał), który przekręcił słowa pielęgniarki „mocz do analizy”.

Widz ma okazję poznać instrumenty muzyczne. Ich prezentacja upodabnia się do pokazu mody. Każdy instrument zostaje określony informacjami na jego temat. W dźwięku fletu jest „więcej świstu i gwizdu niż czegokolwiek”; powietrze z oboju uderza oboiście do głowy, dlatego oboistom przysługuje bezpłatna opieka psychiatryczna; klarnet - ma być prosty do opanowania; fagot - „to najbardziej elegancki instrument filharmoniczny”, brzmi jak "skarga jałówki na złego inseminatora", drewno do jego wykonania leżakuje dziesięć lat razem z fagocistą; waltornia zaskakuje czystym dźwiękiem samych waltornistów, toteż często łysieją, wkładając do niej głowę w poszukiwaniu źródła własnych fałszów, a miłe w niej jest to, że mieści się tam półlitrowa butelka; trąbka - trębacze ostrzegali przed obcymi wojskami, ochraniali dyliżanse przed Indianami, niektórzy byli rabusiami jak Quinto, a trąbista Filharmonii Dowcipu szydełkuje. Puzon - jest naprawdę długi po rozłożeniu, więc prawa ręka puzonisty jest dłuższa od lewej. Tuba zaś była znana Rzymianom, którzy odstraszali mniej muzykalnych barbarzyńców, i jest to jedyny instrument dęty, do którego można się przytulić. W innym występie zaprezentowano altówki. Ich rolą w orkiestrze jest akompaniament, więc kolejno wykonywane partie walców przez altówki brzmią podobnie i składają się z niewielu dźwięków, dopóki nie dołączy do nich reszta zespołu. Przytoczony dowcip o altowiolistach podaje, że nie chorują na grypę, bo nawet wirus ma swój honor. Malicki określa za to fortepian i siedzącego przy nim pianistę jako coś pięknego, do czego dążyła cała historia muzyki, a orkiestra ma być od siedzenia w kanale (bo tak nazywa się miejsce instrumentalistów w operze), oraz ma do fortepianu stosunek bałwochwalczy, co w scenie ma doprowadzić do złości orkiestrę i dyrygenta. Operę zaś od fortepianu odróżnia to, że w nim klapa jest na początku.

Na scenie zaprezentowane są umiejętności głosowe solistów. O sopranach już wspomniałam. Baryton według Malickiego ma służyć do umierania (i wykonuje przy prezentacji właśnie arię taką scenę prezentującą), a tenor jest w zespole operowym z powodów merkantylnych i do późniejszej odsprzedaży. Na koniec skeczu wszyscy soliści wykonują „operowy szlagier", czyli Jožina z Bažin Ivana Mladka.

Popisy Filharmonii Dowcipu to przede wszystkim pokaz wirtuozerii muzyków, którzy mogą grać, tańcząc, a nawet grać i wykonywać taneczne ruchy, siedząc, skakać w trakcie śpiewu lub dyrygowania (tak jest wykonywany Gummy Bear), wykonać pewne utwory w alternatywny sposób, ścigać się z sobą, kto szybciej zagra (na przykład W grocie króla gór - utwór jest grany coraz szybciej). Maestro Malicki zaskakuje odbiorcę, pokazując, że można zagrać skomplikowany utwór jedną ręką (Błękitna rapsodia) albo grać, nie patrząc na klawiaturę - mając głowę schowaną pod marynarką. Są to techniki zaskakujące dla widza, który nie opanował gry na fortepianie. W rzeczywistości granie na instrumencie jest odruchem warunkowym, więc jest możliwe bez spoglądania na instrument.

Ważną funkcję pełnią więc ruchy i gesty. Jak pisze Michał Bruliński ${ }^{21}$, muzyk może grać nie tylko na instrumencie, ale także robić to mimiką oraz gestami. Często stosuje je mimowolnie, wyrażając przy tym emocje. Wpływa to na interpretację odbiorcy - nieznający się na muzyce słuchacz rozpozna fałsz po zmartwionej minie wykonawcy. Wspomniany badacz Waldemara Malickiego wspomina jako polski przykład zjawisko, w którym muzyka jest połączona z widowiskiem, a miny oraz motoryka są istotne. Muzycy wytwarzają swój image

21 M. Bruliński, Czy pianiści to również aktorzy, czyli kilka refleksji o geście w muzyce, „Kwartalnik Młodych Muzykologów UJ" 2015, nr 26 (3), s. 44-56.

Dziennikarstwo i Media 15, 2021

(C) for this edition by CNS 
sceniczny, z którym są kojarzeni, a także są w stanie tym zainteresować publiczność. A więc muzyk może być jednocześnie aktorem.

\title{
Piosenka kabaretowa
}

Ciekawym zagadnieniem jest piosenka kabaretowa. Michael Fleischer ${ }^{22}$ zalicza muzykę, zwłaszcza piosenkę, do typowych akustycznych środków kabaretowych, wskazując ją jako element charakterystyczny dla wielu grup kabaretowych. Z pewnością ta formacja wpisuje się w ten nurt, wyróżniający się własnymi kompozycjami. Piosenka kabaretowa to zagadnienie o tyle problematyczne, że dziś jest zwykle czymś, co towarzyszy początkowi, końcowi lub przerwie w programie, a jeśli wykonują ją kabareciarze - zwykle jest to ogólnie znana melodia z nowym tekstem. Lub po prostu dany utwór jest wykonany w nietypowy sposób. Chętnie sięga się po zabiegi parodystyczne. Nie zdarza się już natomiast często, by było kontynuowane to, co reprezentowały Qui pro Quo, Kabaret Starszych Panów, Tey, Pod Egidą, Elita czy Potem - czyli piosenka napisana właśnie na potrzeby kabaretu. I tekst, i melodia. Jeszcze w minionej epoce piosenka w kabarecie była czymś częstym oraz lubianym przez publiczność. Współczesne grupy zdają się jednak ułatwiać sobie pracę, używając gotowej melodii. Anna Głuszak ${ }^{23}$ stawia tezę, że tekst kabaretowy można wygłosić jako wiersz, ale to melodia ułatwia percepcję. I tak właśnie jest - to, co śpiewane, lepiej zapada w pamięć, odbiorca może piosenkę zanucić, co dawniej było zwłaszcza istotne dla kabaretów politycznych. Kabareciarnia Laskowika jest o tyle wyjątkowa, że wykorzystuje oryginalne piosenki ze specjalnie napisanymi słowami. Wśród twórców tekstów i muzyki są Zenon Laskowik, Władysław Sikora, Grzegorz Luterek, Przemysław Mazurek, Krzysztof Kiełpiński. Piosenki kabaretowe często mają błyskotliwą puentę, pojawia się i tutaj. Odcinki programu rozpoczynają się i kończą piosenkami, pierwsza zaprasza do spektaklu, druga dziękuje publiczności. Warto wymienić niektóre spośród wielu utworów:

\section{Czerwony Kapturek}

Zenon Laskowik posługuje się aluzją literacką, nawiązując do znanej baśni opisanej przez Charles'a Perraulta i braci Grimm. Bohaterka nie jest jednak, jak wspomniałam, małą dziewczynką, która idzie do babci:

\author{
Idzie Czerwony Kapturek \\ Szpetny jak jasna cholera. \\ Twarz ma bardzo pomarszczoną, \\ Chudy bardziej niż chabeta, \\ Idzie z podniesioną głową. \\ Ma ochotę na faceta! ${ }^{24}$
}

Czerwony Kapturek zwraca się do wilka „Wilku! Tyś kawał faceta! Chodź, skoczymy gdzieś na boczek”. Wilk jednak stwierdza, że jest pod ochroną i mówi „Spadaj, ty... paskudo!". Kapturek próbuje go jednak kusić, kładąc się w trawie, zadzierając sukienkę... Zwierzę starało się wytrzymać, lecz z powodu słabych nerwów zjadło Kapturka. Na końcu podane są morały, co formą upodabnia opowieść do wersji Perraulta - czyli:

22 M. Fleischer, op. cit., s. 7.

${ }^{23}$ A. Głuszak, Muzyka i piosenka popularna jako narzędzia opozycji politycznej w Polsce w latach 80. XX wieku, Warszawa 2014, s. 61.

24 „Laskowik \& Malicki. Niedziela Wieczór”, TVP 2009-2010.

Dziennikarstwo i Media 15, 2021

(C) for this edition by CNS 
Pierwszy ważny w zdrowia sprawie:

Że nie zawsze złapiesz wilka, kładąc się na zimnej trawie.

Drugi morał trąci głupstwem,

Chociaż jest nie byle jaki,

Jeśli nie chcesz zostać trupem,

Nie wywołuj wilka w krzaki.

I na koniec prawda szczera,

Choć też głupstwa nutkę niesie,

Jeśliś brzydki jak cholera,

Nie zaczepiaj zwierząt w lesie! ${ }^{25}$

\section{Moja niania była z Poznania}

Zenon Laskowik, artysta poznański, śpiewa piosenkę o niani z Poznania. Bohaterka reprezentuje stereotypy związane z Wielkopolską. Niania „miała talent do zabraniania”, a także do oszczędzania, i „była lepsza od księdza w kazaniach”, miała zawsze na względzie moralność. Pilnowała jej u podopiecznego, niejednokrotnie używała paska. „Nie wolno, nie wolno, mówiła w kółko / I grożąc palcem, marszczyła czółko"26. Zabraniała podmiotowi lirycznemu sikać z balkonu, zwłaszcza komuś na głowę, co doprowadzało go do rozpaczy. Wieczorem uczyła go grać w warcaby, aby nie miał lubieżnych snów, wymagała, by trzymał ręce na kołdrze, grożąc, że dostanie „smary” (wyraz gwarowy oznaczający „lanie”), „straci jurność”, popsuje sobie wzrok. Niania jest także wzorem patriotyzmu, jej zasady mają być ponadczasowe.

\section{Piosenka o dżentelmenach}

Piosenka wykonywana przez Laskowika, Tomczaka, Piątka, Fedorowicza. Aktorzy we frakach i cylindrach śpiewają, że "seks jest niegodny dżentelmena”, „śmieszne ruchy” i „jęki w poduchy" srodze hańbią. Na końcu zaś ściągają cylindry, rozluźniają szale i wyśpiewują puentę: „Lecz uprzedzamy wszystkie damy / My nie jesteśmy dżentelmenami Jakby co!”27.

Ukazany jest więc stereotyp mężczyzny, który lubi seks.

\section{Chomiki}

Kompozycja Krzysztofa Kiełpińskiego opowiada o nieszczęśliwie zakochanym chomiczku "mieszkającym na wyspie zielonej od łez”, który ma nadzieję zdobyć serce chomiczki mieszkającej na „atolu czarnym jak żal”. Zakochane zwierzątko pragnie zbudować łódeczkę, lecz ukochana cechuje się nieczułością i jest zapatrzona w konika morskiego. Wymowa tekstu jest właściwie dramatyczna, a nie śmieszna. Widza mogą bawić ruchy przy słowach „I nie spotkali się, nie / Lecz wąsikami wyczuwali się" - artysta naśladuje małego gryzonia, użycie gry słów „Dla kogo chomikujesz usta swe? Dla kogo chomikujesz usta swe?"28, jak również samo sprowadzenie tragicznej miłości do relacji między dwoma małymi zwierzątkami - co jest złamaniem zasady decorum.

\section{5. Świtezianka}

Tekst w dużej mierze zawiera nieco zmienione cytaty z ballady Adama Mickiewicza ${ }^{29}$. Refren jest po angielsku „I'll dance, I'll cry, I'll be singing all the night. / I'll be waiting, 'till you

\footnotetext{
25 Ibidem.

26 Ibidem.

27 Ibidem.

28 Ibidem.

29 Sam Kiełpiński twierdził na koncercie zespołu rockowego Wake Up (Poznań 2012), którego był
} liderem, że Adam Mickiewicz został zapytany o zgodę na użycie jego tekstu i wieszcz nie zaprotestował. 
fall into my arms"30. Nie kończy się jednak tragicznie dla bohatera, ten zapewnia ukochaną o swoich uczuciach i nie ma mowy o zdradzie. Tekst był właściwie pisany z okazji ślubu znajomych wykonawcy ${ }^{31}$. Kończy się słowami „Będę śpiewał, będę grał, całą noc będę stał. No tak długo aż nie powiesz mi tak!", kwestia jest wyśpiewywana w stronę grających na scenie kobiet, by finalnie nastąpił dialog z publicznością „no tak długo, aż nie powie mi ktoś »tak!«"32. Publiczność przytakuje, co świadczy o dobrym kontakcie nadawcy z odbiorcą. Słowa refrenu i melodia, jak podkreślił sam autor, miały nawiązywać do pieśni irlandzkich (choć w aranżacji Chmielarza nie jest to dosłyszalne), często improwizowanych, co miało związek z tym, iż młoda para to Polka i Irlandczyk.

\section{My już mozim}

W tekście użyta jest zabawna stylizacja językowa - mianowicie naśladowanie języka czeskiego. Pewne cechy języka zostają zachowane, jednak użyte są wyrazy i formy tam niewystępujące. „Ja sem narkomanek, dumam cały ranek, jakie drażi dzisiaj brać”, „Bo my już mozim, mozim, mozim, my już mozim se naprochować [...]. My już mozim na legalu w żyłku sobie dać" ${ }^{33}$. Podmiot liryczny wspomina, że spotkał postaci znane z czechosłowackich seriali dla dzieci - Rumcajsa, Krecika, Rumburaka. Przywołana jest znana z reklamy piwa Tyskie „babička z Chřanova”. Piosenka została ułożona z powodu zniesienia w Czechach kar za posiadanie marihuany, nie, jak mylnie podano przed jej wykonaniem, legalizacji „lekkich” narkotyków (choć w tekście były wymienione te, które pod to określenie się nie kwalifikują). Utwór podsumowuje komentarz Malickiego - „I pomyśleć, że myśmy od Czechów kiedyś chrzest przyjęli”34, co kontrastuje z grzesznymi czynnościami opisanymi w teście piosenki.

\section{Waka-waka}

Piosenka okolicznościowa. Komentarz do przygotowań do mistrzostw świata w piłce nożnej Euro w 2012 roku, zawierający pytanie, czy na pewno uda się przygotować i jak wypadną polscy sportowcy. Tekst nawiązuje zwrotem „Waka-waka” do hymnu igrzysk Euro 2012 „Piłka nożna i śpiew, Waka-waka, fajnie jest! Wuwuzela, trąba słonia - It's time for Polonia!", jednak ani melodia, ani tekst nie są zbieżne z utworem Shakiry. Sytuacja przed zawodami zostaje podsumowana słowami „Gdy jest euforia, gdy jest entuzjazm / Zdarza się też kontuzja, / Cieszmy się wszyscy umiarkowanie, / Pomyślmy co po tym Euro zostanie? / Może być tak, a może być kac, to od nas zależy, czy będą się z nas śmiać!”.

\section{Klocki Lego}

Wykonywany przez Kiełpińskiego i Mikołajczak, a napisany przez Sikorę utwór to manifest indywidualizmu i asertywności, stwierdzenie, że nie wszystko musi być takie samo i nie należy ulegać wszystkiemu z powodu nacisku otoczenia. „Nie chcę jak klocek Lego pasować do wszystkiego - chcę mieć własne zdanie! Po co pozwolenie na nie?" ${ }^{35}$. Nie ma wymowy w żaden sposób śmiesznej czy komicznej.

\footnotetext{
30 „Laskowik \& Malicki. Niedziela Wieczór”, TVP 2009-2010.

31 Zostało to wyjawione także podczas jednego z koncertów zespołu Wake Up.

32 „Laskowik \& Malicki. Niedziela Wieczór”, TVP 2009-2010.

33 Ibidem.

34 Ibidem.

35 Ibidem.
}

Dziennikarstwo i Media 15, 2021

(C) for this edition by CNS 


\section{Alkohol}

Skoro został poruszony wątek kobiecy, warto omówić stereotyp często dotyczący mężczyzn - ponieważ dotychczas zostało wspomniane jedynie zainteresowanie płci męskiej sferą seksualną. Drugim popularnym stereotypem jest, że mężczyźni lubią napoje alkoholowe. Jest to częsty motyw w polskich tekstach humorystycznych i komicznych, a także w innych światowych tekstach, i to od zamierzchłych czasów - znajdziemy go nawet w sagach skandynawskich. Obserwując przedstawienia kabaretowe, trudno wskazać grupę, która nie miałaby w repertuarze ani jednego skeczu dotyczącego tego zagadnienia. Warto na tym się skupić, bo, co ciekawe, w programie "Laskowik \& Malicki” dowcipy dotyczące alkoholu nie pojawiają się z takim natężeniem jak w innych programach związanych z kabaretem i padają raczej z ust pianisty. Malicki stwierdza na przykład, że kobieta przychodzi do domu, poddaje się zabiegom pielęgnacyjnym i makijażowi, co mężczyzna zastępuje jednym piwem. Albo dwoma, jeśli jest brzydki. Stwierdza także, że w (zazwyczaj) błękitnych oczach Słowianina „widać chęć do walki za wolność naszą i waszą, tęsknotę za ojczyzną oraz przytuleniem butelki". Fortepian opisuje jako wyjątkowo męski instrument, na którym można coś postawić, na przykład pół litra, a jako najlepszą cechę waltorni wymienia to, że można zmieścić w niej butelkę. Zapowiadając poemat symfoniczny Finlandia, którego nazwę określa jako wdzięczną (wywołując skojarzenia właśnie z wódką), mówi, że narody polski i fiński dzieli morze, które jest wielkie, ale schłodzone da się wypić. Warto zaznaczyć, że na polskiej scenie kabaretowej bardzo rzadko przedstawia się pijaną kobietę, a w opisywanym przeze mnie widowisku - w ogóle.

W Kabareciarni temat alkoholu wydaje się to krytyką nałogu, to próbą rozliczenia się Zenona Laskowika z naznaczoną nałogiem przeszłością. Przykładów wystąpienia motywu jest dosłownie kilka.

W scenie przedstawiającej kalejdoskop matrymonialny postać grana przez Piątka mówi o sobie: „Polak, katolik, degustator win. Pozna panią bez nałogów”36. W głosie słychać, że jest nietrzeźwa. Wydaje się to ironią w kontekście zestawienia wiary oraz pochodzenia, czyli dobrze kojarzonych wartości, z alkoholizmem, który jest wadą. Zasygnalizowane zostaje, że może zaistnieć patologiczny związek, w którym jedna strona będzie cierpieć. W skeczu pt. Staszek, co się z nami dzieje ${ }^{37}$ dwóch mężczyzn pije wódkę. Przychodzi anioł i ostrzega jednego z nich, że alkohol rujnuje mu rodzinę i zdrowie. Mężczyzna odpędza go słowami „koniec widzenia!" ${ }^{38}$, na co boski posłaniec odpowiada, że jeszcze wróci, co może sygnalizować, że dobro jednak finalnie wygra. Puenta dowcipu nie jest zabawna: główny bohater zwraca się do drugiego, mówiąc, że musi z nim pić, bo jest jego odbiciem w lustrze.

Zupełnie pozbawiony komizmu jest skecz poświęcony psychomachii. Po środku sceny siedzi Laskowik, ma przed sobą stół, na którym stoi butelka. Z jego prawej strony stoi postać ubrana na biało i oświetlona niebieskim światłem, z lewej - na czarno, oświetlona światłem barwy czerwonej. Postaci, które można śmiało identyfikować z siłami dobra i zła, z diabłem i aniołem, kolejno podsuwają lub zabierają bohaterowi butelkę. Przy okazji cytują wiersz Paradoksalne przykazania. Mimo wszystko Keitha M. Kenta, mylnie przypisywany Matce Teresie. Pełny tekst utworu brzmi tak:

\footnotetext{
36 Ibidem.

37 Ibidem.

38 Ibidem.
}

Dziennikarstwo i Media 15, 2021

(C) for this edition by CNS 
Ludzie są nierozumni, nielogiczni i samolubni

KOCHAJ ICH, MIMO WSZYSTKO.

Jeśli czynisz dobro, to ludzie oskarżą cię o egoistyczne motywy

CZYŃ DOBRO, MIMO WSZYSTKO

Jeśli odnosisz sukcesy, zyskujesz fałszywych

przyjaciół i prawdziwych wrogów

ODNOŚ SUKCESY, MIMO WSZYSTKO

Twoja dobroć zostanie zapomniana już jutro

CZYŃ DOBRO, MIMO WSZYSTKO

Szlachetność i szczerość czynią cię podatnym na zranienie

BĄDŹ SZLACHETNY, MIMO WSZYSTKO

To, co budujesz latami, może runąć $\mathrm{w}$ ciągu jednej nocy

BUDUJ, MIMO WSZYSTKO

Ludzie naprawdę potrzebują twojej pomocy,

mogą cię jednak zaatakować, gdy im pomagasz

POMAGAJ, MIMO WSZYSTKO

Dasz światu to, co masz najlepszego, a otrzymasz cios w zęby

DAWAJ ŚWIATU NAJLEPSZE, CO MASZ, MIMO WSZYSTKO.

Temat alkoholu poruszam, ponieważ jest najsmutniejszą i najbardziej refleksyjną częścią spektaklu. Kabareciarz postanawia skrytykować swój dawny problem, widać to w jego stwierdzeniu, że jego żona jest dziwna, że z nim mimo wszystko wytrzymała w związku. Kolejnym sygnałem są przeprosiny wobec byłych współpracowników, wypowiedziane w roku 2010, w amfiteatrze, podczas festiwalu w Opolu - artysta przyznaje się, że jego zachowanie wynikało z choroby alkoholowej.

\section{Wnioski}

Wniosków, jakie można wyciągnąć z twórczości Laskowika i Malickiego, jest kilka. Sztuka wysoka i masowa nie muszą być stawiane po przeciwnych stronach kultury. Lider Filharmonii Dowcipu powiedział, że muzykę rozrywkową od klasycznej oddziela czas, bo to, co komponował Mozart, pełniło wtedy takie funkcje jak dziś muzyka popularna. Sztuka rozrywkowa ma w sobie funkcje kulturotwórcze. Johan Huizinga w swym tekście Homo ludens: zabawa jako źródło kultury ${ }^{39}$ wskazuje na zabawę, a więc rozrywkę, jako coś pierwotniejszego niż sama kultura. Zabawa często związana jest ze śmiechem i kulturą masową, to są typowe ludyczne cechy programów humorystycznych.

Jakikolwiek temat poruszany jest w widowiskach kabaretowych (w wypadku Filharmonii Dowcipu także, gdyż jest ona tworem pokrewnym) dowcip polega zazwyczaj na stereotypie - wyolbrzymianiu go lub zaprzeczeniu. Wskazane przeze mnie formacje wyolbrzymiają stereotypy dotyczące płci, ale łamią te, które dotyczą muzyki. Stosuje się tu ponadto także

39 J. Huizinga, Homo ludens. Zabawa jako źródło kultury, Warszawa 2011.

Dziennikarstwo i Media 15, 2021

(C) for this edition by CNS 
wszelkie środki, jakie zwykle zawierają teksty kabaretowe. Jest parodia, satyra, trawestacje, cytaty, stylizacje, zapożyczenia z innych języków, niedopowiedzenia, parafrazy. W wypadku muzyki pod dyrygenturą Bernarda Chmielarza także można mówić o parodii, stylizacji i parafrazie, nawet o cytatach. Zatem, co należy podkreślić, wręcz immanentną cechą kabaretu oraz innych widowisk humorystycznych są same stereotypy, jak też intertekstualność w ogóle. Ale przede wszystkim chodzi tu o to, by zaskoczyć widza, co, jak wspomniał mi Zenon Laskowik w 2012 roku po koncercie w Mrągowie, jest istotne, by kabaret bawił.

Humor może mieć walory edukacyjne, o czym świadczy to, że Malicki zaznajamiał publiczność z pojęciami muzycznymi, znanymi kompozycjami oraz twórcami. Można w ten sposób propagować sztukę uważaną za doskonalszą od kabaretu mimo towarzyszącego temu dowcipu, niejednokrotnie rubasznego. Być może łamaniem antycznej zasady stosowności, polegającym na wykonywaniu w sposób zabawny muzyki klasycznej, a popularnej w sposób typowy dla poważnej, muzycy przyczyniają się do propagowania „niemodnych" już form muzycznych, w tym opery, filharmonii.

$\mathrm{Na}$ edukacyjną funkcję humoru, zjawisk z obszaru kabaretu i jego pogranicza zwraca uwagę Kamila Osip ${ }^{40}$. Wskazuje ona autokrytykę jako jedno z narzędzi edukacyjnych kabaretu, a za taką można uznać wątki alkoholowe, które są zainspirowane zdarzeniami z życia Laskowika. Zatem sztuka niepoważna, kojarzona ze śmiechem, może mieć charakter refleksyjny, od którego współcześni widzowie się odzwyczaili (a przecież twórcy tacy jak Tuwim czy artyści kabaretu Pod Egidą mieli w swym repertuarze utwory o zupełnie poważnym charakterze!). Nabiera przez to cech moralizatorskich. Można zatem przekazać widzowi między dowcipami wartości, które twórca uważa za istotne.

Zagadnienia kabaretu, humoru muzycznego, kwestii kobiecych to tematy, które można rozpatrywać na wiele sposobów i ciągle wymagające dalszych prac filologów, teatrologów, socjologów, muzykologów.

\section{Bibliografia}

Appignanesi L., Kabaret, przeł. A. Kreczmar, Warszawa 1975.

Błąd Ł., Cabaret in Poland - Polish cabaret, [w:] Polish Humour, „Humour and Culture” 2, red. D. Brzozowska, W. Chłopicki, Kraków 2012, s. 175-220.

Błąd Ł., Mikrut I., Polska piosenka kabaretowa - zarys wybranych nurtów i zjawisk, [w:] Humor polski, „Humour and Culture" 4, red. D. Brzozowska, W. Chłopicki, Kraków 2014, s. 425-444.

Bruliński M., Czy pianiści to również aktorzy, czyli kilka refleksji o geście w muzyce, „Kwartalnik Młodych Muzykologów UJ" 2015, nr 26 (3), s. 44-56.

Chudziński M., Reżyserować siebie, https://bosko.pl/kultura/Rezyserowac-siebie.html (dostęp: 20.02.2021).

Deszczyński K., Kuglarze, Poznań 2018.

Domagalski A., Kwiatkowski L., Kabaret w Polsce 1950-2000, Kraków 2015.

Dziemidok B., Czy sens i znaczenie współczesnej sztuki popularnej sprowadza się do jej wartości rozrywkowych?, „Estetyka i Krytyka” 2001, nr 20, s. 47-64.

Dziemidok B. O komizmie - od Arystotelesa do dzisiaj, Gdańsk 2009.

Dziemidok B., Sztuka popularna w kontekście współczesnej moralności i obyczajowości, „Konteksty Sztuki - Konteksty Estetyki" 2011, nr 2, s. 69-82.

Fleischer M., Zarys teorii kabaretu, http://www.fleischer.pl/text/zarys_teorii_kabaretu.pdf (dostęp: 29.11. 2021).

40 K. Osip, Z czego się śmiejecie? Czyli sztuka kabaretowa w perspektywie edukacyjnej, „Kultura Społeczeństwo - Edukacja” 2012, nr 1, s. 205-223.

Dziennikarstwo i Media 15, 2021

(C) for this edition by CNS 
Fox D., Aktorstwo kabaretowe - zabawa, zawód, sztuka, [w:] Od symbolizmu do post-teatru, red. E. Wąchocka, Warszawa 1996, s. 114-124.

Fox D., Polski kabaret - tradycja i współczesność, „Postscriptum Polonistyczne” 2011, nr 8, s. 123-124.

Grzegorek J.N., O potrzebie poszukiwania i tworzenia wartości, „Rocznik Naukowy Kujawsko-Pomorskiej Szkoły Wyższej w Bydgoszczy. Transdyscyplinarne Studia o Kulturze Edukacji” 2015, nr 10, s. 158195.

Jaki jest kabaret?, red. D. Fox, J. Mikołajczyk, Katowice 2012.

Kiec I., Historia polskiego kabaretu, Poznań 2015.

Kiec I., W kabarecie, Wrocław 2004.

Kłys A., Smoleń B., Niestety wszyscy się znamy, Kraków 2011.

Krasowska A., Od Zielonego Balonika do Potem, komizm słowny w kabarecie literackim, Warszawa 2013.

Lubowicka G., Rozumieć codzienność - z punktu widzenia teorii interpretatywnej Clifforda Geertza, http:// repozytorium.uni.wroc.pl/Content/79625/PDF/Lubowicka_Grazyna_Rozumiec_codziennosc.pdf (dostęp: 11.04.2021).

Nycz R., Parodia i pastisz. Z dziejów pojęć artystycznych w świadomości literackiej XX wieku, [w:] idem, Tekstowy świat. Poststrukturalizm a wiedza o literaturze, Warszawa 1993, s. 233-235.

Osip K., Z czego się śmiejecie? Czyli sztuka kabaretowa w perspektywie edukacyjnej, „Kultura - Społeczeństwo - Edukacja" 2012, nr 1, s. 205-223.

Sikora W., Śmieszne a dobre, http://sikora.art.pl (dostęp: 20.02.2021).

Stępień T., O satyrze, Katowice 1996.

Ślęzak L., Kabaret Pod Egidą, Tey, Elita i „Studio 2002” wobec rzeczywistości PRL-u, „Szkice Humanistyczne” 2018, nr 1-2, s. 45-65.

Wodniczak K., Spojrzenia nie tylko na Teya, Poznań 2010.

\title{
Filmografia
}

\author{
"Laskowik \& Malicki" \\ Polska 2009-2010 \\ Reżyseria: Jacek Kęcik \\ Scenariusz: Jacek Kęcik \\ Wykonawcy: Zenon Laskowik, Waldemar Malicki, Kabareciarnia Laskowika, Filharmonia Dowcipu \\ Produkcja TVP
}

Dziennikarstwo i Media 15, 2021

(C) for this edition by CNS 